\title{
DO DEBATE EPISTEMOLÓGICO À CLÍNICA INTERDISCIPLINAR DE DIREITOS HUMANOS DA UNIRG
}

FROM THE EPISTEMOLOGICAL DEBATE TO THE UNIRG'S INTERDISCIPLINARY CLINIC OF HUMAN RIGHTS

Jaqueline de Kassia Ribeiro de Paiva

Juliana Ricarte Ferraro

Lady Sakay

\section{RESUMO}

Este artigo analisa dados obtidos em Grupos Focais, para a construção coletiva da proposta de criação de uma Clínica Interdisciplinar de Direitos Humanos (CIDH), envolvendo os cursos da UnirG. Trata-se de pesquisa qualitativa e participante, com Coordenadores de Estágios dos cursos da universidade. Conclui que os participantes veem positiva a integração entre os cursos, no aspecto acadêmico e para os serviços prestados, e promissora a criação da CIDH, cuja temática é Saúde e Qualidade de Vida. A investigação contribuiu para o debate sobre interdisciplinaridade no ensino superior e permitiu a construção coletiva da proposta de criação da CIDH na UnirG.

Palavras-chave: Grupo Focal. Interdisciplinaridade. Educação em Direitos Humanos. 


\section{ABSTRACT}

This article analyzes data obtained in Focus Groups for the collective construction of the proposal to create an Interdisciplinary Human Rights Clinic (IHRC), involving the UnirG courses. This is a qualitative and participant research, with Staging Coordinators of the university courses. It concludes that the participants see positive the integration between the courses, in the academic aspect and for the services provided, and promising the creation of the IHRC, whose theme is Health and Quality of Life. The research contributed to the debate on interdisciplinarity in higher education and allowed for the collective construction of the proposal for the creation of the IHRC at UnirG.

Key words: Focus Group. Interdisciplinarity. Human Rights Education.

\section{INTRODUÇÃO}

A Universidade de Gurupi - UnirG é uma entidade Pública Municipal de Ensino Superior, localizada no sul do Tocantins, em Gurupi, cuja manutenção é atribuição da Fundação UnirG, com personalidade jurídica de direito público, criada pela Lei Municipal n. 611, de 15 de fevereiro de 1985 , e alterações posteriores. ${ }^{1}$ Seu corpo estudante em 2018-2 é de 4.135 (quatro mil cento e trinta e cinco) estudantes, selecionados em vestibulares semestrais.

A Instituição de Ensino Superior (IES) possui 16 (quinze) cursos de graduação ofertados nas seguintes áreas de Ciências sociais aplicadas (Ciências Contábeis, Comunicação Social-Jornalismo, Administração e Direito), Ciências médicas e da saúde (Medicina, Farmácia, Enfermagem, Fisioterapia e Odontologia, Educação Física - Bacharelado), Ciências humanas (Pedagogia, Psicologia, Educação Física - Licenciatura), Linguagem e Artes (Letras), Engenharia e Computação (Ciência da Computação e Engenharia Civil).

A IES atua no tripé ensino, pesquisa e extensão. Em razão de seu tempo de existência, 32 anos, existem constantes discussões sobre os cursos de graduação, gestão acadêmica, desenvolvimento institucional, dentre outros. Na temática de extensão, os projetos pedagógicos citam a criação de ligas acadêmicas em diversos cursos de graduação, e mais 
de 25 projetos de pesquisa sob o comando da Pró-Reitoria de Pesquisa e Pós-Graduação (PROPESQ). Outro ponto de avanço citado pelos seus PPCs também é a capacitação dos docentes via programas de mestrado, firmados em parceria com outras instituições para capacitação dos corpos docente e administrativo.

Este artigo analisa os dados obtidos a partir da realização de Grupos Focais $^{2}$, para a construção coletiva da proposta de criação de uma Clínica Interdisciplinar de Direitos Humanos, envolvendo os cursos da UnirG, cujos resultados podem servir de exemplo para outras universidades. Foram realizados 02 (dois) grupos focais com a participação de Coordenadores de Curso, Coordenadores de Estágio e professores interessados na temática de direitos humanos. Optou-se por utilizar as reuniões do Colégio de Coordenadores, já programadas para os meses de setembro e outubro, com a prévia permissão da Pró-Reitoria de Graduação e Extensão (PGRAD) e dos coordenadores.

0 resultado final foi submetido ao Edital para projetos de extensão 2018 e ao Conselho Superior Acadêmico (CSA), para análise da viabilidade de implantação. Espera-se que este projeto sirva de base para discussões de políticas públicas de ensino superior, especialmente na temática dos direitos humanos na UnirG.

Além desta introdução, este artigo apresenta e analisa os resultados do Grupo Focal 1, as questões do diferencial semântico em relação às categorias estudantes, professor supervisor de estágio e usuários do serviço da Clínica de Direitos Humanos. Em seguida apresenta e analisa as discussões do Grupo focal 2, com levantamento das temáticas, bem como das estratégias para construção coletiva do Projeto de Clínica de Direitos Humanos, para a instituição. Por último apresenta as considerações finais.

\section{RESULTADOS E DISCUSSÕES DO GRUPO FOCAL 1}

Na primeira reunião realizada, no dia 12 de setembro de 2018, iniciou-se às 14 horas e finalizou às 16 horas e 30 minutos, contou-se com a presença de vinte pessoas, as quais foram convocadas para a reunião do Colégio de Coordenadores. Após o fim da primeira parte da reunião em que 
foram tratados assuntos da Pro-reitoria de Graduação (PGRAD), passouse a palavra ao moderador da pesquisa, que esclareceu a necessidade da presença de pelo menos um representante de cada curso, e sanadas as dúvidas apresentadas, permaneceram na reunião 14 (catorze) pessoas.

Conforme o planejamento, o grupo focal 1 objetivou analisar a viabilidade institucional de realizar uma proposta interdisciplinar nos estágios dos cursos, com sete questões. A pesquisa iniciou com a pergunta: Quando pensa em uma prática de estágio em conjunto com outros cursos, qual a primeira ideia que lhe vem à cabeça?

Quadro 2 - Relatos dos participantes sobre o trabalho em conjunto com outros cursos

\begin{tabular}{|c|c|}
\hline $\mathbf{P}$ & Fragmentos de fala dos participantes \\
\hline B1: & $\begin{array}{l}\text { "[...] mas eu vejo vários outros cursos atuando como, por } \\
\text { exemplo, engenharia [...]" }\end{array}$ \\
\hline B2: & $\begin{array}{l}\text { "[...] O que me vem à cabeça a primeira coisa: é que esse estágio é } \\
\text { totalmente interdisciplinar, ele vai dar um espaço bem maior de } \\
\text { conhecimento para nosso Acadêmico }[. . .] \text { " }\end{array}$ \\
\hline B3: & “[...] a gente precisa basicamente de todas as outras áreas [...]” \\
\hline B4: & $\begin{array}{l}\text { "[...] a prestação de serviço de todos os cursos dentro dessa } \\
\text { clínica então assim consegui ver um projeto muito interessante } \\
\text { desta maneira }[. . .] \text { " }\end{array}$ \\
\hline B5: & $\begin{array}{l}\text { "[...] levantar dentro da própria comunidade, dentro dos líderes } \\
\text { comunitários, as necessidades realmente a serem tratadas dentro } \\
\text { do estágio conjunto. [...]" }\end{array}$ \\
\hline B6: & $\begin{array}{l}{[\ldots . .] \text { eu imagino que a comunicação ela se entrelaça com praticamente }} \\
\text { tudo né, com todos os projetos e ações que a instituição realiza, } \\
\text { porque as pessoas precisam ter acesso à informação [...]" }\end{array}$ \\
\hline B7: & $\begin{array}{l}\text { "[...] eu acho que os cursos poderiam contribuir nesse sentido, na } \\
\text { vertente, digo assim, no SUS de forma geral [...]" }\end{array}$ \\
\hline B8: & $\begin{array}{l}\text { "[...] vai suprir uma carência dessa efetivação do trabalho } \\
\text { interdisciplinar [...]" }\end{array}$ \\
\hline B9: & $\begin{array}{l}\text { "[...] vejo a clínica como a possibilidade de atuação de diversos } \\
\text { cursos na clínica, trazendo a resolutividade, trazendo a integralidade, } \\
\text { atendimento integral aos pacientes, ao público, [...]" (continua) }\end{array}$ \\
\hline
\end{tabular}




\begin{tabular}{|c|l|}
\hline P & Fragmentos de fala dos participantes \\
\hline B10: & $\begin{array}{l}\text { "[...] a gente poderia colaborar com as pessoas e interagir com o } \\
\text { curso de Direito, com o curso de Contábeis, Pedagogia, Farmácia, } \\
\text { Comunicação, nesse sentido, de criar novos negócios que } \\
\text { potencializem a economia, que promovam a melhoria da qualidade } \\
\text { de vida dessas pessoas [...]" }\end{array}$ \\
\hline B11: & $\begin{array}{l}\text { "[...] Bom, meu curso, acho que ele pode colaborar, deve colaborar } \\
\text { na questão do ensino-aprendizagem [...]" }\end{array}$ \\
\hline B12: & $\begin{array}{l}\text { "[...] nós vamos ganhar muito mais com isso do que contribuir, } \\
\text { porque a imprescindível esse contato com outras profissões que } \\
\text { nós não temos, e isso começa desde a formação, porque nós temos } \\
\text { Acadêmicos que não sabe se posicionar com o outro, nossa profissão } \\
\text { não se preocupa com outro, nós somos muito técnicos então isso vai } \\
\text { contribuir muito para o Acadêmico. [...]" }\end{array}$ \\
\hline B13: & $\begin{array}{l}\text { "[...] em primeiro lugar pensamos no trabalho em equipe, uma } \\
\text { oportunidade dos estágios se conhecerem, se ajudar [...]" }\end{array}$ \\
\hline B14: & $\begin{array}{l}\text { "[...] acho que tem muito a agregar tanto para a comunidade quanto } \\
\text { também tem muito a agregar com nosso aluno, como cidadão também, } \\
\text { dentro dessa realidade fora, e a realidade dos outros colegas, dos } \\
\text { outros alunos, principalmente para nossos alunos da Medicina [...]" }\end{array}$ \\
\hline
\end{tabular}

Fonte: As autoras, (Q1-GF 1, 12/09/2018)

Na transcrição das falas acima, os participantes conseguem visualizar os cursos atuando dentro de seus campos específicos de conhecimento, em conjunto com outros cursos, em uma perspectiva positiva, tanto no processo de ensino e aprendizagem quanto na melhoria da qualidade dos seus próprios serviços prestados à comunidade. Relevante notar ainda a possiblidade de contribuição para humanização do próprio aluno, o qual é educado de forma isolada de outras profissões, e até mesmo da comunidade, "muito técnico (...) não se preocupa com o outro" (B12, GF1, 12/09/2018), sugerindo um isolamento acadêmico e social.

Os currículos dos cursos são tradicionais e baseados na especialização, em que pese os professores reconhecerem a complexidade atual mundial, e necessidade de superação dos limites impostos pelas matrizes curriculares, de modo a garantir seu espaço no campo profissional. Para Siqueira (2003, p.1), a organização do currículo tradicional 
baseia-se na "hiperespecialização", e tal deveria ser substituído pelo "reconhecimento da complexidade do mundo atual", pela suplantação de limites "epistemológicos, psicossociológicos, institucionais".

A própria LDB fomenta a cooperação, o trabalho coletivo e a edificação de um PPP participativo e colaborativo, gerado no seio da comunidade acadêmica, atribuindo identidade à IES e ao curso, trazendo mais flexibilidade e abertura para inovações curriculares nas graduações, consentâneas às inovações sociais e científicas, especialmente quando nivela o tripé ensino, pesquisa e extensão.

É um anseio da equipe participante a produção de novos saberes e a solução de problemas reais da comunidade, de maneira ampla e abrangente. 0 que se propõe é uma profunda revisão de pensamento, que deve caminhar para intensificar o diálogo, as trocas e a integração conceitual e metodológica nos distintos campos do saber. A dinamicidade social corre a passos largos das inovações acadêmicas e reestruturação de ideias.

Na segunda pergunta, buscou-se respostas sobre os serviços prestados ao público, por cada curso, nos campos de estágio, com a seguinte indagação: Qual o principal serviço de atendimento prestado ao público, que seu curso pratica nos campos de estágio?

Todos os cursos apresentam uma prestação de serviço à comunidade, dentro de suas áreas específicas, contudo, trabalhando isoladamente. Mesmo nessa perspectiva já sedimentada por tantos anos, os participantes conseguem visualizar uma prática de atuação em conjunto com os demais cursos, sem que isso prejudique a qualidade dos serviços educacionais ou profissionais prestados, conforme se verá abaixo, com as transcrições das falas para a terceira rodada de discussões.

Pelo contrário, todos os participantes veem como enriquecedor a contribuição de outros cursos para seus trabalhos, numa visão pedagógica interdisciplinar. Eis a síntese das respostas: 
Quadro 3 - Relatos dos participantes sobre os serviços prestados ao público, por curso

\begin{tabular}{|c|c|}
\hline $\mathbf{P}$ & Fragmentos de fala dos participantes \\
\hline B1: & $\begin{array}{l}{[\ldots] \text { pratica a parte preventiva e curativa nas áreas de clínica geral, }} \\
\text { Odontologia, periodontia, cirurgia, prótese, câncer bucal, pediatria, } \\
\text { cirurgia buco maxilo [...]" }\end{array}$ \\
\hline B2: & $\begin{array}{l}\text { "[...] nosso curso pratica a docência e intervenção pedagógica nos } \\
\text { campos [...]" }\end{array}$ \\
\hline B3: & $\begin{array}{l}\text { "[...] parte de docência e o estágio que nós fazemos no atendimento } \\
\text { mais aprofundado [...]" }\end{array}$ \\
\hline B4: & $\begin{array}{l}{[\text { "...] formalização como empreendedor individual, organizações de }} \\
\text { associação de bairro, orientação por questões financeiras, e declaração } \\
\text { de imposto de renda [...]" }\end{array}$ \\
\hline B5: & “[...] organização Empresarial e estratégias organizacionais [...]” \\
\hline B6: & $\begin{array}{l}\text { "[...] prevenção e promoção, nas questões curativas da saúde da } \\
\text { Mulher, da criança, do Adolescente, e paciente adulto, paciente } \\
\text { idoso, a gente também atua na atenção primária em todas essas } \\
\text { áreas e na atenção especializada do paciente de baixo risco e de } \\
\text { alto risco também [...]" }\end{array}$ \\
\hline B7: & $\begin{array}{l}\text { "[...] basicamente é a criação de material, seja jornalístico, seja de } \\
\text { material publicitário [...]" }\end{array}$ \\
\hline B8: & $\begin{array}{l}\text { “[...] projeto para ampliação e reforma, principalmente na questão } \\
\text { de regularização de imóvel [...]" continua }\end{array}$ \\
\hline $\mathbf{P}$ & Fragmentos de fala dos participantes \\
\hline B9: & $\begin{array}{l}\text { "[...] na parte de atenção primária e secundária nas UBS; no hospital } \\
\text { e no ambulatório onde tem algumas especialidades médicas [...]" }\end{array}$ \\
\hline B10: & $\begin{array}{l}\text { "[...] estágios através da assistência farmacêutica nas unidades } \\
\text { básicas de saúde, por meio da Farmácia Comunitária que nós temos, } \\
\text { assistência farmacêutica ou farmácia Clínica no âmbito hospitalar [...]" }\end{array}$ \\
\hline B11: & $\begin{array}{l}\text { "[...] através do serviço escola, que é a clínica de psicologia, atua no } \\
\text { atendimento Clínico individual e em grupo, crianças e adolescentes, } \\
\text { adultos e idosos e também tem atuação de estágio nas escolas [...]" }\end{array}$ \\
\hline B12: & $\begin{array}{l}{[. . .] \text { com atenção primária e especialidades, faz atendimentos }} \\
\text { domiciliares com Acadêmicos do quinto período, também tem } \\
\text { o maio ganho de atendimento é na Clínica escola que é mais por } \\
\text { especialidade [...]" }\end{array}$ \\
\hline
\end{tabular}




\begin{tabular}{|c|l|}
\hline B13: & $\begin{array}{l}\text { "[...] abrange licenciatura e bacharelado então atuamos na Escola de } \\
\text { Educação Infantil Fundamental e Médio, também temos o estágio } \\
\text { lazer Esporte e o estágio em academia que é o fitness [...]" }\end{array}$ \\
\hline B14: & "[...] atua na assistência jurídica à população carente [...]" \\
\hline
\end{tabular}

Fonte: As autoras (2018), (Q2, GF1, 12/09/2018)

Nesse sentido, não se trata de transformar a Interdisciplinaridade em uma superciência, mas servir de referência aos movimentos pedagógicos que visam à integração dos saberes (OLIVEIRA, 2016). Trata-se de uma substituição da concepção fragmentária para a unitária do ser humano (FAZENDA, 1995, 2002).

E esta forma de pensar se harmoniza com a educação clínica, elemento central deste trabalho, marcada pela diversidade, por permitir que diferentes ramos do saber desenvolvam projetos diversos, em torno de causas semelhantes (RIBEIRO, 2016, p. 18). Especialmente no curso de Direito, este modelo apresenta-se transformador, não só no aspecto metodológico, mas principalmente quanto à percepção de que outras áreas do saber podem contribuir para uma melhor prestação dos serviços.

Na visão de Huerta apud Villarreal e Courtis (2007, p. 6), o ensino clínico se apresenta como a ferramenta ideal para desenvolver nos alunos, habilidades dialéticas, críticas, astúcia no trato com clientes, assessoria, interrogatórios, dentre outros. Mostra-se modificador do tradicionalismo do ensino jurídico ao criar nos estudantes, percepções críticas e inovadoras através de estudo de caso concreto. Deste modo, a interdisciplinaridade pode não produzir o resultado esperado ou insuficiente, mas, de outra banda, pode trazer ganho de espaços, e aos poucos, modificar o pensamento disciplinarizante, voltado aos interesses de alguns (SEVERO; DE PAULA, 2010, p.35).

Percebe-se, na UnirG, a ausência de uma política institucional efetiva de apoio a propostas pedagógicas incentivadoras da interdisciplinaridade entre os cursos. Política que poderia integrar e incentivar a interligação dos diferentes ramos dos saberes aos quais pertencem os cursos ofertados. Ato contínuo, a próxima questão foi: Em que medida, outro curso da Universidade, poderia contribuir positivamente para este serviço prestado? 
Quadro 4 - Relatos dos participantes sobre a contribuição dos cursos para seus serviços

\begin{tabular}{|c|c|}
\hline $\mathbf{P}$ & Fragmentos de fala dos participantes \\
\hline B1: & $\begin{array}{l}\text { "[...] eu acho que esses cursos principalmente tem uma atuação muito } \\
\text { específica com a nossa área [...]" }\end{array}$ \\
\hline B2: & $\begin{array}{l}\text { "[...] todos os cursos têm como dar um apoio, todos nossos } \\
\text { tem uma relação [...]" }\end{array}$ \\
\hline B3: & $\begin{array}{l}\text { "[...] eu acredito que todos os cursos podem ajudar, mas eu consegui } \\
\text { visualizar um trabalho mais em conjunto entre a contabilidade, com } \\
\text { letras, com direito e administração [...]" }\end{array}$ \\
\hline B4: & $\begin{array}{l}\text { "[...] para enfermagem em praticamente todos os cursos têm o } \\
\text { poder de resolutividade maior, pra gente não olhar o paciente só } \\
\text { naquela questão do momento, a gente podia tá fazendo essa contra- } \\
\text { referência indicando outras profissões para estarem cuidando } \\
\text { de outras áreas [...]" }\end{array}$ \\
\hline B5: & $\begin{array}{l}\text { "[...] todos os cursos podem contribuir conosco e nós podemos } \\
\text { contribuir com todos [...]" }\end{array}$ \\
\hline B6: & $\begin{array}{l}\text { "[...] na engenharia o curso que teria mais afinidade para contribuir } \\
\text { conosco seria a parte do direito [...]" }\end{array}$ \\
\hline B7: & $\begin{array}{l}\text { "[...] enfermagem dá para trabalhar com todo mundo, pensando em } \\
\text { indivíduo, no coletivo, no problema geral dele [...]" }\end{array}$ \\
\hline B8: & $\begin{array}{l}\text { "[...] ele pode contribuir principalmente com relação à orientação } \\
\text { de medicamento onde entra Odonto, enfermagem, a medicina, } \\
\text { psicologia, fisioterapia [...]" }\end{array}$ \\
\hline B9: & $\begin{array}{l}\text { "[...] então eu vejo a contribuição numa grande escala de todos, não } \\
\text { tem não tem como excluir nenhum [...]" }\end{array}$ \\
\hline B10: & $\begin{array}{l}\text { "[...] a gente também precisa todo mundo precisa né, então, assim, } \\
\text { eu vejo dentro de saúde pública, um trabalho mutuo, de todos os } \\
\text { cursos da instituição [...]" }\end{array}$ \\
\hline B11: & "[...] eu acho que todos podem ajudar [...]" \\
\hline B12: & $\begin{array}{l}\text { "[...] a gente precisa ser mais atuante, mais acolhido pelos outros } \\
\text { cursos mais antigos da área da saúde }[\ldots] "\end{array}$ \\
\hline B13: & $\begin{array}{l}\text { "[...] E aí eu não consigo excluir, nessa situação, excluir nenhum curso } \\
\text { todos poderiam dar sua contribuição para o nosso estágio [...]" }\end{array}$ \\
\hline
\end{tabular}

Fonte: As autoras, (Q3, GF1, 12/09/2018) 
Dos relatos extraídos, conclui-se que os cursos percebem capacidade de ajuda mutua, de forma positiva, interligando-se saberes aparentemente fora das áreas de conhecimento específicos, quase uma intuição ao saber e fazer interdisciplinar. Algumas áreas do conhecimento, em razão da afinidade do campo teórico, tornam-se mais simples a visualização da interdisciplinaridade, em outras, mesmo em campos teóricos distintos, é possível o trabalho coletivo. Isso mostra que a academia é um terreno fértil para práticas interdisciplinares e trabalho com Direitos Humanos, faltando apenas um espaço e metodologia adequados.

Lapa (2014, p. 92) diz que "o conhecimento é, portanto, concebido como uma construção coletiva, em que todos os participantes - educandos e educadores, estudantes e facilitadores - são seres inacabados e sujeitos no processo de ensino-aprendizagem"

Em seguida, no planejamento, viria a seguinte rodada de discussões: "De que maneira você imagina uma interação pedagógica de seu acadêmico/ estagiário com acadêmicos/estagiários de outros cursos?” Contudo, em razão das respostas apresentadas nos itens anteriores, estas questões já haviam sido debatidas, e esta temática ficou respondida na anterior. $\mathrm{Na}$ releitura das manifestações, extraiu-se o seguinte:

Quadro 5 - Relatos sobre a interação pedagógica entre os discentes de outros cursos.

\begin{tabular}{|c|l|}
\hline P & Fragmentos de fala dos participantes \\
\hline B1: & $\begin{array}{l}\text { "[...] no caso de odontologia tem especificamente, o curso de psicologia } \\
\text { que pode atuar dentro do processo [...] Pedagogia [...] Comunicação } \\
{[\ldots] \text { Medicina [...] Enfermagem [...] Psicologia [...]" }}\end{array}$ \\
\hline B2: & $\begin{array}{l}\text { "[...] psicologia daria maior apoio para nós [...], a educação } \\
\text { física [...] enfermagem [...] medicina com a nossa pedagogia } \\
\text { hospitalar [...] fisioterapia" }\end{array}$ \\
\hline B3: & $\begin{array}{l}\text { "[...] eu consegui visualizar um trabalho mais em conjunto entre } \\
\text { a contabilidade, com letras, com direito e administração [...] é } \\
\text { importante essa parceria [...]" }\end{array}$ \\
\hline B4: & $\begin{array}{l}\text { "[...] a gente podia tá fazendo essa contra-referência indicando outras } \\
\text { profissões para estarem cuidando de outras áreas [...] Odonto, a fisio, } \\
\text { a medicina, farmácia, psicologia, educação física e o direito" }\end{array}$ \\
\hline
\end{tabular}




\begin{tabular}{|c|c|}
\hline B5: & $\begin{array}{l}\text { "[...] todos os cursos podem contribuir conosco e nós podemos } \\
\text { contribuir com todos [...] nós precisamos de informações completas } \\
\text { e atualizadas [...]" }\end{array}$ \\
\hline B6: & "[...] saber até onde a gente pode ir para poder auxiliar ele [...]" \\
\hline B7: & $\begin{array}{l}\text { “[...] enfermagem dá para trabalhar com todo mundo [...] dá para } \\
\text { extrair situações que vá depender da situação, dá para trabalhar } \\
\text { em conjunto sim, [...]" }\end{array}$ \\
\hline B8: & $\begin{array}{l}\text { "[...] onde entra Odonto, enfermagem, a medicina, } \\
\text { psicologia, fisioterapia" }\end{array}$ \\
\hline B9: & $\begin{array}{l}\text { "[...] temos como principal atuação redistribuir para os } \\
\text { outros cursos [...]" }\end{array}$ \\
\hline B10: & $\begin{array}{l}\text { "[...] um trabalho mutuo, de todos os cursos da instituição, a fim de } \\
\text { estar melhorando as condições dos nossos trabalhos nos pacientes [...]" }\end{array}$ \\
\hline B11: & $\begin{array}{l}\text { "[...] o que falta minha visão é ter uma interação de professores e } \\
\text { alunos, que fica na observação, e se a gente puder inteirar melhor } \\
\text { com aluno, aluno com professor, professor/professor [...] então a } \\
\text { gente estende aos outros cursos, que quiserem frequentar o nosso } \\
\text { estágio e fazer qualquer outra parceria, para que a gente possa } \\
\text { ter êxito e sucesso" }\end{array}$ \\
\hline B12: & “[...] então a gente tem assim, um corpo com a maioria deles [...]” \\
\hline B13: & $\begin{array}{l}\text { "[...] o nosso atendimento lá revela inúmeros outras necessidades } \\
\text { do assistido [...] a princípio não se pensa nessa parceria, mas a } \\
\text { necessidade existe, ela é real [...] eu não consigo excluir, nessa situação, } \\
\text { excluir nenhum curso [...]" }\end{array}$ \\
\hline
\end{tabular}

Fonte: As autoras, (Fragmentos de Q1, Q2 e Q3, GF1/12/09/2018)

Os cursos se veem interligados num trabalho em conjunto, alguns mais relacionados ao campo teórico comum, em princípio. Chama a atenção que mesmo pertencendo a campos teóricos distintos, os participantes veem possibilidades de interação em praticamente todos os cursos, conforme visualizado na Figura 1. 
Figura 1 - Possibilidades de Interdisciplinaridade entre os cursos, na perspectiva dos participantes dos grupos focais

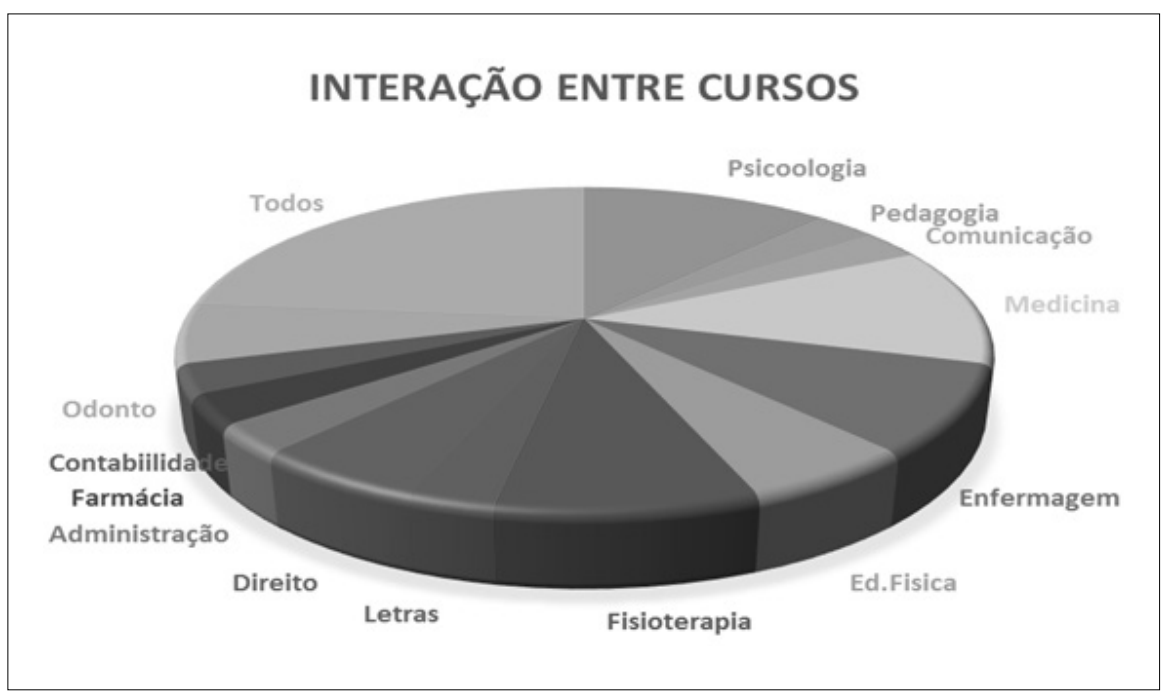

Fonte: As autoras, (Fragmentos de Q1, Q2 e Q3/GF1, 12/09/2018)

Verifica-se a possibilidade de aplicação de uma técnica educativa eficaz para a metodologia participativa que é a de solução de problemas (problems solving), na qual os discentes, a partir de uma situação concreta identificam as possíveis soluções para a questão, tanto nos mecanismos internos quanto externos, articulando a interdisciplinaridade. As possibilidades são muitas, pois além do estudo da estratégia, que já acontece em sala de aula, ao terem a prática concreta, irem a campo, terem contato com as vítimas, verem os impactos de suas ações, os estudantes podem realmente ver e sentir o caráter instrumental de seu aprendizado, além de vivenciarem o caráter social e transformador do estudo do Direito e, em especial, dos Direitos Humanos (LAPA, 2014, p. 93).

Falar da realidade como algo parado, estático, compartimentado e bem-comportado, quando não falar ou dissertar sobre algo completamente alheio à experiência existencial dos educandos, vem sendo, realmente, a suprema inquietação desta educação. (FREIRE, 1997, p. 65) 
Quanto à crença de que o processo ensino/aprendizagem ser garantido numa interação, todos os participantes, afirmaram categoricamente suas concordâncias. Por isso, percebe-se o respeito à premissa de que a interdisciplinaridade faz relação entre as disciplinas e a realidade, entre os educadores articulados num trabalho coletivo, de maneira a superar a fragmentação do ensino, apta a fomentar uma visão globalizada de mundo, a enfrentar e solucionar problemas apresentados aos discentes na atualidade.

Esta interação possibilitará aos estudantes suma instigação à análise de fenômenos sociais, políticos, econômicos, históricos e culturais e que, assim, pratiquem a interdisciplinaridade:

A própria questão do ensino interdisciplinar é uma proposta que tem de ser bem mais explicitada. A maioria dos juristas vê o ensino interdisciplinar como a inclusão no currículo de uma série de disciplinas de outras áreas do conhecimento e que propiciem, cada uma delas, a sua visão do fenômeno jurídico, trazendo, dessa forma, ao aluno, um conjunto de visões diferenciadas. Este tipo de visão propiciará uma série de visões estanques sobre o mesmo objeto, sem contudo propiciar ao aluno uma visão de sua totalidade. (RODRIGUES et al, 2007, p. 17)

Tal constatação também foi retirada das outras rodadas de perguntas, quais sejam: Como os professores/supervisores de estágio podem contribuir para este processo? Esta prática de estágio, em sua visão, se harmoniza com a temática de direitos humanos? Para este questionamento, todos responderam afirmativamente. Como já estava no final da reunião, percebeu-se um desconforto entre os participantes em permanecerem por mais tempo e a esta questão, especialmente, responderam de forma uníssona, justificando aqui a ausência de transcrição detalhada das falas.

0 principal questionamento que surge nesse momento para a proposta do projeto, é como uma clínica de Direitos Humanos fará acontecer a interdisciplinaridade do ensino, pesquisa e extensão? Nas palavras de Lapa, citando Rodrigues (2007, p. 19)

Ela estaria contemplada se: a) tivermos professores de diferentes departamentos participando da análise dos casos?; ou b) analisarmos textos e bibliografia de várias áreas do saber? Entendemos que não seja somente 
isso. Se trouxermos diferentes pontos de vista e saberes nos encontros do grupo de estudos da clínica de Direitos Humanos, isso não seria utilizar a natureza multidisciplinar, ou seja, somar várias disciplinas? A interdisciplinaridade não se realiza em um conjunto de disciplinas estanques - isto é multidisciplinaridade - mas sim na análise do objeto a partir de categorias pertencentes a vários ramos do conhecimento em um mesmo momento, buscando apreender todos os aspectos desse objeto, em sua integridade.

Para além de múltiplas análises, é imprescindível o diálogo real, efetivo, concreto, e para tanto, é preciso a abertura dos atores para estas contribuições.

Ao mesmo tempo, percebeu-se que com o avançar das falas, os participantes passaram a se inteirar mais, ficarem bem à vontade para expressarem suas opiniões, de modo que o assunto fluiu de maneira bem natural, e em alguns momentos, chegaram a antecipar as discussões, o que prejudicou a ordem das proposituras, porém, preservando o conteúdo e profundidade das considerações.

De fato, a técnica de grupo focal valoriza a interação grupal para a geração de dados, tendo em vista que as pessoas são estimuladas a falar sobre experiências e pontos de vista sobre determinado tema.

As discussões em grupo permitiram aos participantes trocar, concordar ou discordar sobre opiniões, atitudes e experiências, constituindo-se em um recurso valioso para explorar o ensino por meio de Clínicas em Direitos Humanos.

\section{DIFERENCIAL SEMÂNTICO: ESTUDANTES, PROFESSORES E USUÁRIOS}

Em seguida foi explicada a tabela de diferencial semântico, esclarecidas as dúvidas e todos fizeram a marcação, conforme abaixo:

H.1 Gostaria de saber como você imagina um acadêmico autor de seu próprio aprendizado: 
Quadro 5 - Diferencial Semântico para a categoria Estudante

\begin{tabular}{|l|c|c|c|c|c|l|}
\hline ADJETIVO & $\mathbf{1}$ & $\mathbf{2}$ & $\mathbf{3}$ & $\mathbf{4}$ & $\mathbf{5}$ & ADJETIVO \\
\hline Empoderado & 7 & 4 & 3 & & & Descapacitado \\
\hline Integrado & 8 & 3 & 3 & & & Desarticulado \\
\hline Ativo & 10 & 4 & & & & Inativo \\
\hline Construtivo & 9 & 4 & 1 & & & Destrutor \\
\hline Produtivo & 9 & 4 & 1 & & & Improdutivo \\
\hline
\end{tabular}

Fonte: As autoras, (GF1, 12/09/2018).

Em que pese a educação dever ser compreendida e elaborada de maneira interdisciplinar, cujo aluno é o principal agente, pelas respostas acima, percebe-se que $40 \%$ dos docentes ainda não o veem apto a assumir com comprometimento, reponsabilidade, capacidade de elaborar e executar ações, assumir compromissos, decidir ante os fatos e integrar em seu ambiente. Talvez, o próprio educador não perceba que este aluno tenha autonomia suficiente para tanto, e o julgue incapaz de ser autor de seu próprio conhecimento. Tal postura não se harmoniza com o ensino via clínicas, porque, segundo Lapa (p. 89) este é um espaço na universidade que oportuniza aos estudantes vivenciarem essa experiência. A CDH deve adotar uma metodologia que supere a concepção "bancária” da educação.

Para garantir seu espaço no campo profissional, o discente precisa absorver o mundo, sem se limitar em especializações que, conquanto lhe possibilitem exercer a carreira, retiram-lhe a valência exigida pelo universo do trabalho, pois as incitações humanísticas essenciais, específicos e tecnológicos, ao que tudo indica, requerem soluções por conjuntos de profissionais de diversas áreas.

Morin, nesse sentido, fala da importância relevante de uma cabeça bem feita ante uma cabeça bem cheia:

O significado de uma cabeça bem cheia, é óbvio: é uma cabeça onde o saber é acumulado, empilhado e não dispõe de um princípio de seleção e organização que lhe dê sentido. Uma cabeça bem feita significa que, em vez de acumular o saber, é mais importante dispor ao mesmo tempo de: - uma aptidão geral para colocar e tratar os problemas; - princípios organizadores que permitam ligar os saberes e lhes dar sentido (MORIN, 2005, p.21). 
Por isso o conhecimento estribado somente em disciplinas de conteúdos fechados não se apresenta adequado:

Agora bem, devo dizer que, em certo sentido, não creio realmente na possibilidade de elaborar fronteiras totalmente claras entre as disciplinas. Não penso que o mundo está por si mesmo estruturado de acordo com o sistema das disciplinas científicas, mas que aqui temos uma espécie de processo de negociação. Creio que as coisas interessantes são os problemas intelectuais sem resolver. É totalmente secundário se isto é feito por esta ou aquela disciplina. Por exemplo, minha disciplina é a sociologia, mas creio que trago um montão de conhecimentos de outras disciplinas - antropologia, história, filosofia, psicologia, inclusive teologia. Portanto, se trata de um processo de negociação constante entre pessoas que reclamam o direito de tratar com tal ou qual tema dentro de sua disciplina, ou tentam negar esse direito aos demais (BEYTÍA, 2012, p. 378).

Assim, a proposta de educação clínica se apresenta adequada, pois:

A proposta da CLÍNICA DE DIREITOS HUMANOS é ser um espaço universitário que proporcione na formação acadêmica a constituição identitária e profissional dos estudantes, por meio de: a) de uma abordagem participativa em espiral (participatory approach); b) da técnica de solução de problemas (problems solving); e c) do uso de casos emblemáticos/paradigmáticos (LAPA, 2014, p.90).

E a temática dos direitos humanos se amolda perfeitamente nessa tônica, pois "A Educação em Direitos Humanos está comprometida em construir uma cultura de respeito à dignidade humana em todos seus aspectos por meio de práticas e vivências das quais o educando é também protagonista" (CARDOSO, 2013, p. 11).

Sugere-se aqui que o educador trabalhe com afinco o seu dever de transformar este sujeito como ator de sua aprendizagem. Ao ser ativo no processo, o discente saberá planejar, trabalhar com suposições e a solucionar problemas concretos.

No tópico seguinte, foi questionado: H.2 Gostaria de saber como você imagina o professor/supervisor nesta proposta de integração de estágios na Clínica Interdisciplinar de Direitos Humanos: 
Quadro 6- Diferencial Semântico para a categoria professor/supervisor

\begin{tabular}{|l|c|c|c|c|c|l|}
\hline ADJETIVO & $\mathbf{1}$ & $\mathbf{2}$ & $\mathbf{3}$ & $\mathbf{4}$ & $\mathbf{5}$ & ADJETIVo \\
\hline Empoderado & 9 & 5 & & & & Descapacitado \\
\hline Integrado & 10 & 4 & & & & Desarticulado \\
\hline Ativo & 11 & 3 & & & & Inativo \\
\hline Construtivo & 10 & 4 & & & & Destrutor \\
\hline Produtivo & 9 & 5 & & & & Improdutivo \\
\hline
\end{tabular}

Fonte: As autoras (GF1, 12/09/2018)

Os participantes veem o professor numa posição confortável para trabalhar numa proposta pedagógica interdisciplinar, de forma a complementar os métodos, os conceitos, as estruturas e os dogmas sobre os quais se sedimentam as práxis pedagógicas das disciplinas científicas.

Vê-se como positiva o pensamento inovador, da qual resulta uma troca, reciprocidade e integração entre áreas diversas de conhecimento.

Contudo, ao se confrontar este tópico com o primeiro (aluno), percebese que falta ao professor uma visão efetiva da interdisciplinaridade, remetendo-nos ao pensamento de Japiassu (1976) o qual diz que esta proposta é muito pensada e pouco vivida, de fato. Assim, tem-se como um desafio sem precedentes para todos os atores envolvidos nas ciências de políticas públicas, um convite ao diálogo fundado na cooperação e troca.

Deste modo, a crença de que um espaço diferente da sala de aula mostra-se adequado, como uma clínica, integrando a matriz curricular dos cursos, trabalhando casos emblemáticos sobre temas de Direitos Humanos, de maneira a permitir um incentivo para análise dos fenômenos em sua integralidade, porém sob os diversos aspectos, sociais, políticos, econômicos, históricos e culturais e assim, haja a interdisciplinaridade. Segundo Thiesen (2008, p. 545) "de modo geral, a literatura sobre esse tema mostra que existe pelo menos uma posição consensual quanto ao sentido e à finalidade da interdisciplinaridade: ela busca responder à necessidade de superação da visão fragmentada nos processos de produção e socialização do conhecimento". 
Em seguida, buscou-se a percepção sobre o usuário dos serviços: H.3 Gostaria de saber como você imagina o usuário do serviço nesta proposta de integração de estágios na clínica interdisciplinar de Direitos Humanos:

Quadro 7 - Diferencial Semântico para a categoria usuários

\begin{tabular}{|l|c|c|c|c|c|l|}
\hline ADJETIVO & $\mathbf{1}$ & $\mathbf{2}$ & $\mathbf{3}$ & $\mathbf{4}$ & $\mathbf{5}$ & ADJETIVo \\
\hline Acolhido & 10 & 3 & & & 1 & Sozinho \\
\hline Integrado & 8 & 3 & 2 & & 1 & Desintegrado \\
\hline Atendido & 9 & 4 & & & 1 & Desassistido \\
\hline Satisfeito & 10 & 2 & 1 & & 1 & Insatisfeito \\
\hline Encantado & 7 & 5 & 1 & & 1 & Desencantado \\
\hline Humanizado & 12 & 1 & & & 1 & Desumanizado \\
\hline
\end{tabular}

Fonte: As Autoras, (GF1, 12/09/2018)

Aqui, constata-se que a maioria dos participantes vê a comunidade sendo atendida com qualidade, garantindo a prestação do serviço ofertada pelos cursos, em que pese identificar alguns dos participantes divergindo esta opinião, de uma maneira geral, o que sugere um temor na integração, de modo a eventualmente a comprometer o acolhimento do usuário.

Importante este compromisso social, pois é imprescindível para a Clínica de Direitos Humanos, que a sociedade seja acolhida, sem preconceitos, ou visões pré-concebidas, para caminhar rumo a uma mudança efetiva socialmente, de modo a ocorrer a verdadeira sensibilização dos estudantes para com problemas de Direitos Humanos.

Resta evidente neste espaço universitário um compromisso com a Justiça Social e isso demonstra ser este um pressuposto importante para a formação de estudantes. Viu-se que o nascimento das Clínicas de Direitos Humanos em vários países, almejam a sensibilização dos alunos para os temas sociais e contribuem para a transformação ética, humanista, logo, estes docentes percebem a CIDH da UnirG como um ambiente transformador da sociedade, na direção do estabelecimento da Justiça Social. 


\section{RESULTADOS E DISCUSSÕES DO GRUPO FOCAL 2}

Na segunda reunião de grupo focal, realizada nas mesmas condições e lugar da primeira, buscou-se extrair elementos para a construção coletiva da proposta de criação da Clínica Interdisciplinar de Direitos Humanos na UnirG, uma temática a ser desenvolvida que abrangesse todos os cursos.

Fator que chamou a atenção foi a redução do número de participantes, apenas oito pessoas presentes, apenas $50 \%$ do número anterior. A pergunta para extrair esta informação foi: Qual temática lhe parece a mais adequada para a Clínica Interdisciplinar de Direitos Humanos - CIDH da UnirG?

Nesta reunião, de modo a deixar os participantes mais à vontade, e fomentar a espontaneidade, ficaram livres para manifestarem suas opiniões quando sentissem vontade, sem uso do objeto da palavra. A transcrição obedeceu a ordem de participação, porém não se identificou quem falou duas vezes, ou mesmo não quis participar.

Registre-se uma preocupação dos participantes em estabelecer uma escala dedutiva de pensamento, ao dizerem: "É do Macro para o micro", "Nós vamos fazer um contexto geral?", "Nós vamos afunilando", “eixos mais amplos" (G.F 2, 19/09/2018). Durante as discussões, identificou-se a aparição das seguintes temáticas: 
Figura 2 - Temáticas levantadas no GF 2, do dia 19/09/2018

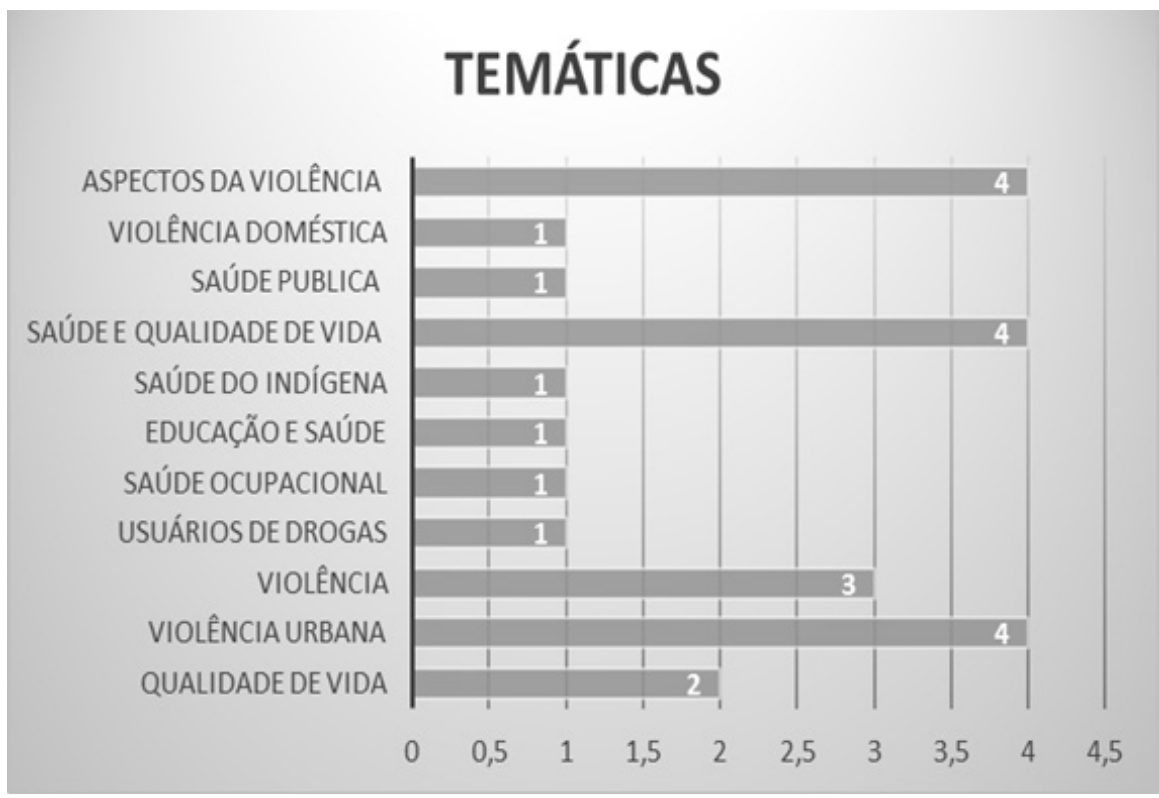

Fonte: As autoras (GF2, 19/09/2018).

Contudo, ao se analisar as temáticas, percebe-se que a temática violência, para o grupo, abrange outras temáticas, tais como aspectos da violência, violência urbana e doméstica o que motivou a consideração de que violência, seus aspectos e tipos fazem parte, e por isso, inseridas em uma única temática, o que faz surgir o seguinte gráfico (Figura 3): 
Figura 3 - Síntese das temáticas levantadas no GF 2, do dia 19/09/2018

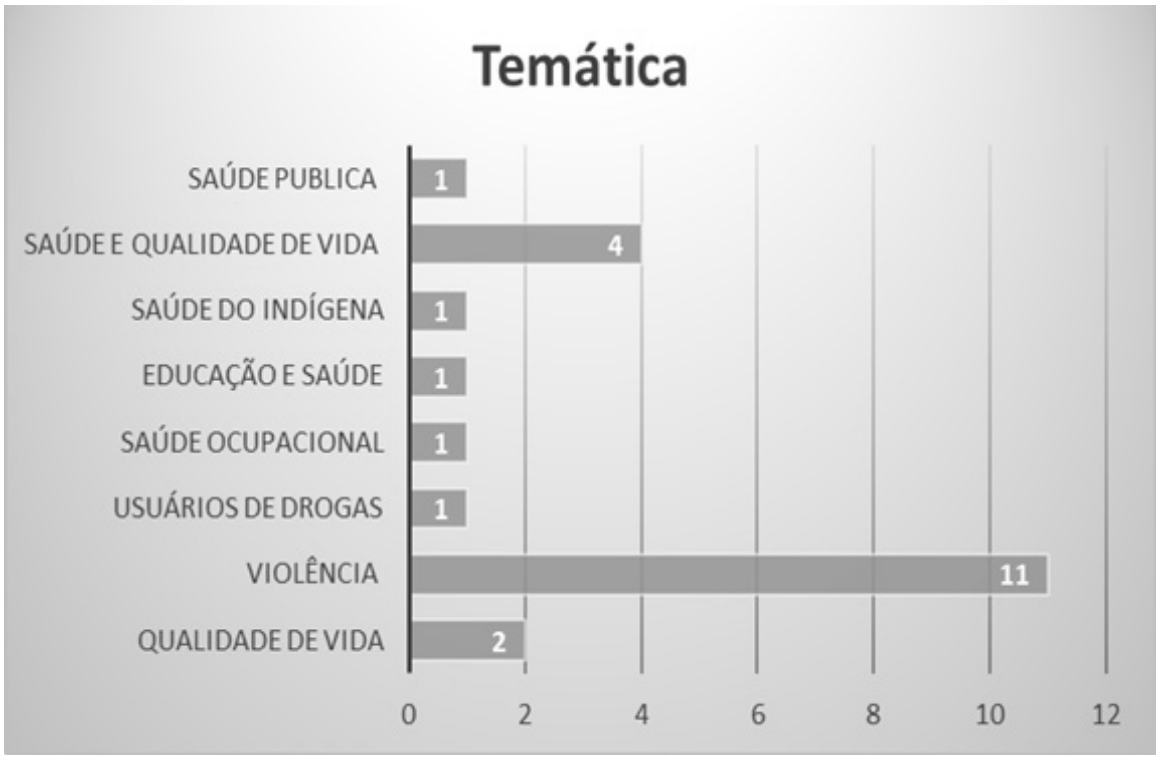

Fonte: As autoras (GF2, 19/09/2018).

Ao longo das discussões, uma das participantes fez uma intervenção que modificou todo esse cenário de escolher a temática violência: "A minha não, a minha seria saúde e qualidade de vida e dentro desse aspecto geral, os temas de violência, de droga, aí sim dá para discriminar porque faz parte dessa saúde em geral, da qualidade em geral” (...) “Que a qualidade seria um eixo temático, dentro desse tema geral, e aí você pode fazer ramificações porque a violência vai restringir eu acho porque são vários temas" (G.F2, 19/09/2018).

Tal assertiva foi confirmada pela moderadora com a seguinte indagação para a qual todos manifestaram concordância: "Então a proposta do grupo é saúde e qualidade de vida e aspectos da violência seria um sub tema a ser desenvolvido pelo curso que se enquadrasse dentro disso?" Portanto, a temática escolhida pelo grupo, para a clínica interdisciplinar de Direitos Humanos da UnirG é Saúde e Qualidade de Vida, pois de acordo com os participantes, a temática violência se insere tanto em saúde, propriamente dita quanto qualidade de vida. 
Seguindo o roteiro, a próxima discussão envolveu a definição dos atores envolvidos na clínica. Neste momento, utilizou-se o objeto da palavra, de modo a facilitar a coleta de todas as informações, por participante. A pergunta foi: Quando se pensa nesta Clínica Interdisciplinar de Direitos Humanos, que tem como eixo temático Saúde e Qualidade de Vida, dentro da IES, em seu curso, quais seriam os atores a se envolverem neste trabalho? (no aspecto, discente docente e a respectivas disciplinas).

Extrai-se que existem disciplinas, em todos os oito cursos participantes deste momento da pesquisa, que poderiam ser envolvidas na Clínica de Direitos Humanos e, ainda, que o grupo visualiza a atividade envolvendo professores e alunos, em todos os momentos do curso de graduação.

Quadro 9 - Atores envolvidos/ disciplinas, segundo participantes.

\begin{tabular}{|c|c|c|}
\hline Partic & Disciplinas & Atores \\
\hline B1: & $\begin{array}{l}\text { "[...] saúde coletiva, educação } \\
\text { física: cultura e sociedade ... } \\
\text { lazer e educação, atividade } \\
\text { física e saúde [...]" }\end{array}$ & $\begin{array}{l}\text { "[...] docentes e } \\
\text { discentes, Estagiários, } \\
\text { (...) alunos a partir do } \\
\text { segundo período [...]" }\end{array}$ \\
\hline B2: & $\begin{array}{l}\text { “[...] pedagogia hospitalar, } \\
\text { (...) jogos e brincadeiras ... } \\
\text { educação e saúde [...]" }\end{array}$ & $\begin{array}{l}\text { "[...] aluno de primeiro } \\
\text { período... professores [...]" }\end{array}$ \\
\hline B3: & “[...] dontologia e sociedade $[. .] ”$. & $\begin{array}{l}\text { "[...] Professores... alunos do } \\
\text { primeiro período [...]" }\end{array}$ \\
\hline B4: & $\begin{array}{l}\text { “[...] saúde pública, farmacologia, } \\
\text { o estágio supervisionado } \\
\text { profissionalizante, } \\
\text { atenção farmacêutica e } \\
\text { farmácia Clínica [...]” }\end{array}$ & "[...] docente... discente $[\ldots] "$ \\
\hline B5: & $\begin{array}{l}\text { “[...] Atenção básica 1, } 2,3 \\
\text { e } 4 \text { ”... saúde e comunidade, } \\
\text { da família e comunidade [...] } \\
\text { disciplinas mais voltadas } \\
\text { às especialidades saúde: da } \\
\text { criança, saúde da Mulher, saúde } \\
\text { mental e as especialidades mais } \\
\text { específicas cardiologia }\end{array}$ & $\begin{array}{l}\text { "[...] alunos do primeiro ao } \\
\text { décimo segundo período [...]" }\end{array}$ \\
\hline
\end{tabular}




\begin{tabular}{|c|c|c|}
\hline B6: & $\begin{array}{l}\text { “[...] rádio }[\ldots] \\
\text { jornalismo comunitário }[\ldots . .] "\end{array}$ & $\begin{array}{l}\text { "[...] Professores, } \\
\text { coordenadores de estágio } \\
\text { e os acadêmicos e também, } \\
\text { os servidores [...]" }\end{array}$ \\
\hline B7: & $\begin{array}{l}\text { "[...] Cultura e Sociedade. } \\
\text { Direitos Humanos e Sociedade } \\
\text { [...] Educação e Sociedade". }\end{array}$ & $\begin{array}{l}\text { "[...] Discentes } \\
{[\ldots] \text { docentes }[\ldots] "}\end{array}$ \\
\hline B8: & $\begin{array}{l}\text { "[...] Social e Comunitária”. } \\
\text { Aconselhamento Psicológico, } \\
\text { Intervenção e Crise, Psicologia } \\
\text { com Pessoas com Populações } \\
\text { Diferenciadas...Psicologia } \\
\text { da Saúde, a Psicologia } \\
\text { Hospitalar...Psicopatologia } \\
\text { Escolar.Psicologia Jurídica, } \\
\text { Dinâmica de grupos e } \\
\text { disciplinas de Estágios [“...]” }\end{array}$ & $\begin{array}{l}\text { ‘...] alunos desde o } \\
\text { primeiro até o décimo } \\
{[\ldots . . .] \text { professores [“...]” }}\end{array}$ \\
\hline
\end{tabular}

Fonte: As Autoras, (Q1, GF2, 19/09/2018).

Importante para a CIDH da UnirG a institucionalização, de maneira a validar horas curriculares ou extracurriculares, pois assim, haverá garantias de que o projeto não fique à mercê de vontades institucionais, e torne-se uma atividade permanente. Bem como se garante nesta ação, a remuneração do trabalho docente, o qual é essencial nesse caminhar.

As atividades de ensino do projeto da CIDH UnirG podem ser desenvolvidas encontros regulares de grupos de estudos dos discentes matriculados nessas disciplinas, semanais ou quinzenais. Podem ainda ser carga horaria complementar destas mesmas disciplinas, na qual eles terão oportunidade de aprofundamento de seus estudos em Direitos Humanos, tanto com os professores quanto com os coordenadores da Clínica, quanto com professores de outras áreas de conhecimento que são convidados para trocar experiências e reflexões sobre os casos a serem trabalhados. Destes grupos, podem surgir propostas de pesquisa de análise de casos reais e/ou hipotéticos envolvendo Direitos Humanos, as quais aprofundarão o conhecimento ou buscarão novas respostas para outras perguntas. 
No momento seguinte, foram discutidos os critérios para seleção do docente para participar do trabalho. A pergunta norteadora do debate foi a seguinte: Quais critérios você pensa serem adequados para a seleção do docente a participar da CIDH da UnirG? Das discussões, extraiu-se o seguinte gráfico (Figura 4).

Figura 4 - Características do professor participante da CIDH UnirG

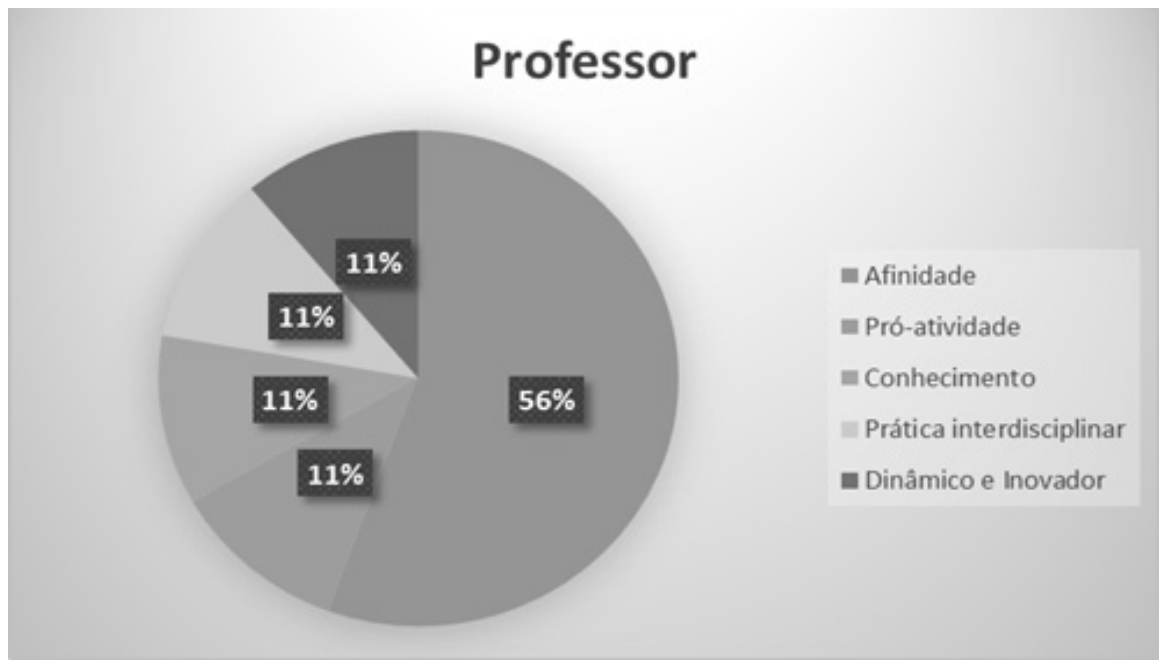

Fonte: As Autoras, (Q2, GF2, 19/09/2018).

O professor inovador e dinâmico, portanto, necessita explorar sua criatividade para resolver questões rotineiras, a partir de novos olhares, antigas e novas questões. Para além de revolucionar todo um sistema a partir de uma simples ideia, são necessárias mudanças cotidianas pautadas pela vontade de tornar melhor o ambiente onde atua.

Resta evidente a necessidade de se conhecer e compreender os vários aspectos do pensamento do docente, e seu conhecimento, bem como as relações desses aspectos com a sua atuação ou comportamento. Por detrás deste interesse, está a conviç̧ão de que aquilo que o professor pensa, influencia de maneira significativa aquilo que o professor faz. Percebe-se que tais características fazem parte do lecionado por Jacques Delors, na síntese de Rodrigues (2018, p. 89) quando diz: 
Aprender a fazer - Não basta preparar-se com cuidados para se inserir no setor do trabalho. A rápida evolução por que passam as profissões pede que o indivíduo esteja apto a enfrentar novas situações de emprego e a trabalhar em equipe, desenvolvendo espírito cooperativo e de humildade na reelaboração conceitual e nas trocas, valores necessários ao trabalho coletivo. Ter iniciativa e intuição, gostar de uma certa dose de risco, saber comunicar-se e resolver conflitos e ser flexível. Aprender a fazer envolve uma série de técnicas a serem trabalhadas.

Entre o fechamento desta discussão e o assunto seguinte, surgiu uma discussão entre os membros integrantes, sobre a participação do aluno na CIDH ser um componente prático curricular das disciplinas indicadas pelos cursos, extensão curricularizada, na qual se incorpora atividades de extensão às matrizes curriculares dos cursos de graduação, ou ainda um campo de estágio para os cursos. Dos debates, extraiu-se a seguinte conclusão (Figura 5).

Figura 5 - Posição da CDH UnirG, no currículo.

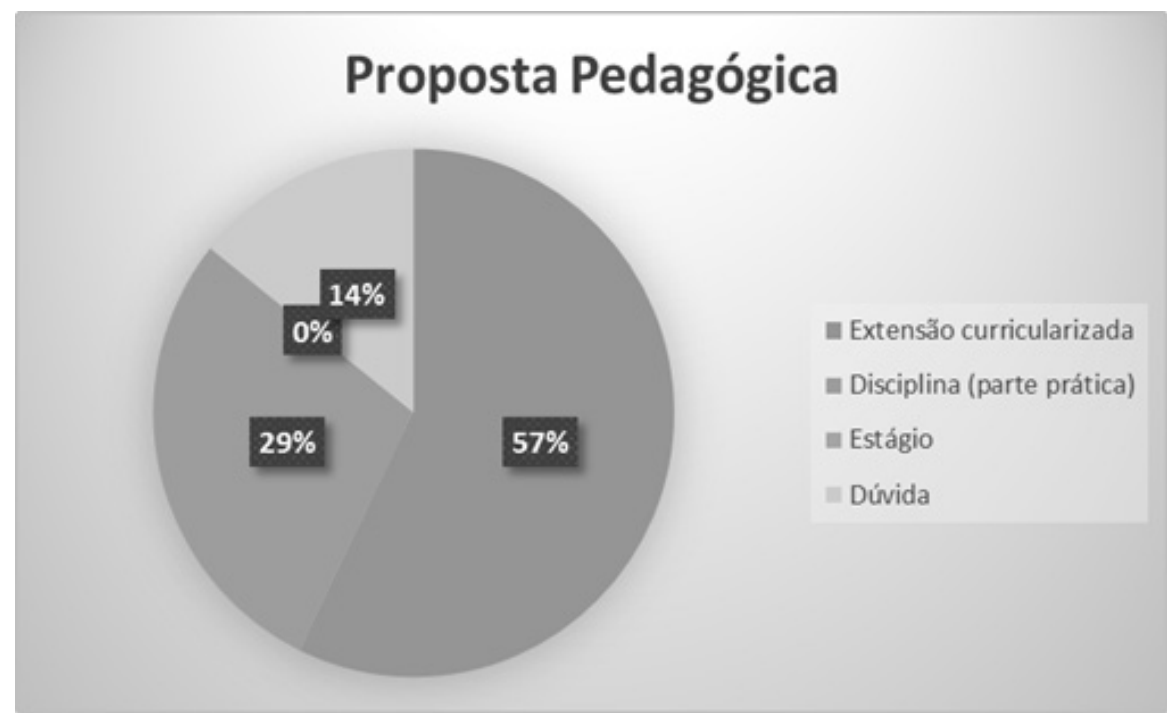

Fonte: As Autoras, (Q2, GF2, 19/09/2018).

Na prática, pode-se dizer que a CIDH da UnirG, segundo a proposta coletiva, é ser um espaço de diálogo e de atuação para garantir ao estudante 
uma relação mais aberta entre os campos dos saberes e conhecimentos disciplinares com as questões mais amplas que norteiam a realidade social e coletiva. Debates epistemológicos e metodológicos no ensino e na pesquisa que fundamentem e ampliem as possibilidades de compreensão dos fenômenos estudados e de práticas inovadoras. Tal processo de curricularizar a extensão atende aos documentos nacionais que versam sobre políticas para a Educação, como o Plano Nacional de Educação 2014-2024, da LDB 9.394/96, das Diretrizes Curriculares Nacionais para o ensino superior e ao Plano Nacional de Extensão, além de documentos norteadores das práticas pedagógicas da Universidade UnirG, via de seus Projetos Políticos Pedagógicos vigentes. Vê-se, portanto, a oportunidade de junção teoria-prática presente na indissociabilidade entre ensino, pesquisa e extensão.

Como sugestão para as atividades de extensão, percebe-se inicialmente duas maneiras de seleção dos casos emblemáticos: a) selecionados por alunos e professores, na rotina da CIDH ou b) quando houver solicitação de atendimento de uma organização/entidade social parceira. Frise-se que em ambos, há um contato com a comunidade externa.

O tema dos Direitos Humanos exige "[...] que o trabalho extensionista articule práticas formativas na graduação fazendo interagir, por exemplo, o estágio curricular ou extracurricular com disciplinas práticas e teóricas, com grupos e projetos de pesquisa, ampliando as possibilidades formais e não formais de abordagem do tema" (ZENAIDE et al, 2010, p. 75). Desta premissa, conclui-se que a CIDH UnirG será um espaço de excelência para integração do ensino-pesquisa-extensão, no qual os estudantes vivenciarão experiências concretas dessa cominação, e tendo consciência de como se articulam.

Esta conclusão de extensão curricularizada não se harmoniza com a forma de seleção indicada pelo grupo para os discentes, pois ao pressupor que os alunos serão selecionados via edital, haverá exclusão de alguns, segundo critérios a serem firmados e a extensão curricularizada pressupõe a frequência de $100 \%$ dos alunos matriculados nas disciplinas afins a serem relacionadas. Contudo, destaque-se que a pergunta norteadora da discussão foi: Quais critérios você pensa serem adequados para a seleção do discente a participar da CIDH da UnirG, conforme visualizado (Figura 6). 
Figura 6 - Critérios para seleção dos estudantes participantes da CIDH

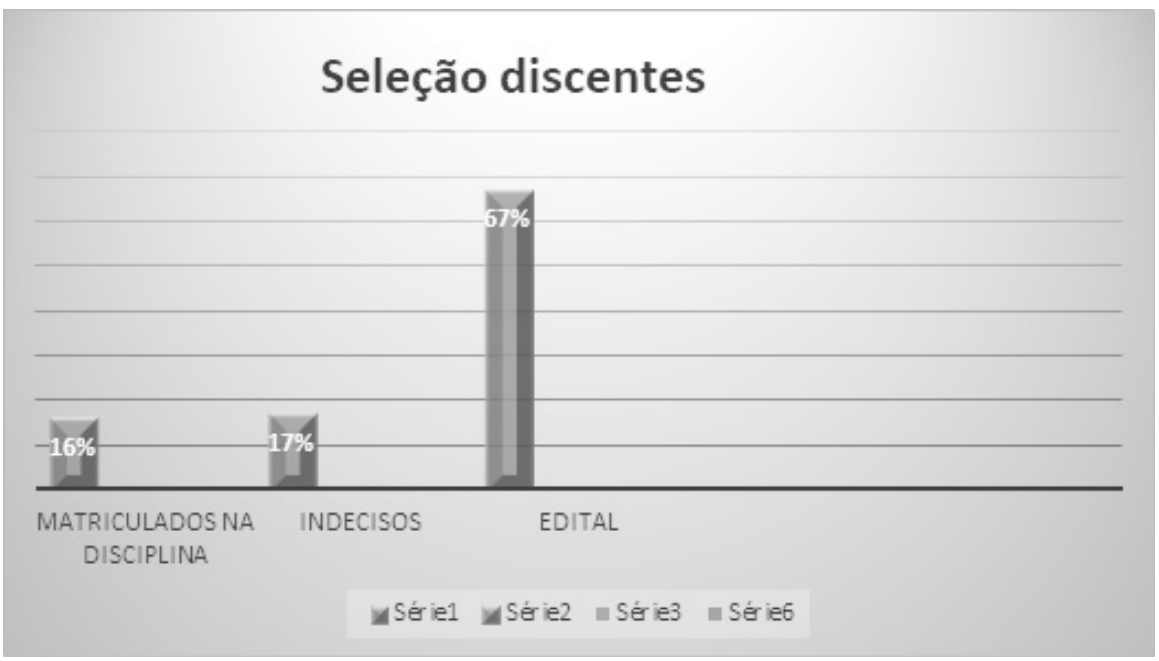

Fonte: As autoras (Q3, GF2, 19/09/2018).

Deste modo, outra não é a conclusão senão de que a CIDH da UnirG, deverá ser uma atividade de extensão, cuja seleção dos discentes participantes se dará por edital. Oportunamente, ao se consolidar esta prática metodológica na instituição, poderá tornar-se possível ampliar para extensão curricularizada também.

Sobre as disciplinas que se harmonizam com a proposta pedagógica, na pergunta norteadora dos atores e disciplinas, os membros já as indicaram conforme matrizes curriculares existentes. Ao ser lido novamente o questionamento, quais critérios você pensa serem adequados para seleção da disciplina a participar da CIDH da UnirG, um participante acrescentou a disciplina Envelhecimento, do seu curso.

Destaque-se neste momento que ao se conceber a CIDH como uma atividade de extensão curricularizada, a IES não necessita atrelála a uma ou algumas disciplinas, o que foge da concepção do ensino exclusivo via disciplinas. Entretanto, esta percepção mostra-se importante para confirmar o tripé indissociável do ensino, pesquisa e extensão. A constatação de que já existem disciplinas dentro do curso que trabalham conteúdos harmônicos com a prática de Direitos Humanos proposta, sugere 
um público alvo de trabalho com concepções teóricas mínimas, os quais necessitam apenas de adaptação a nova metodologia de trabalho, assim como os docentes. Outrossim, é possível ainda, visualizar na Clínica, um amplo espaço de trabalho para parte prática das mencionadas disciplinas, caso haja interesse do docente e discentes no trabalho, e pode inclusive impulsionar o trabalho de pesquisa acadêmica.

Seguindo na linha de construção da proposta coletiva, aos participantes foi questionado sobre a existência de algum outro ator considerado necessário para a implantação/ desenvolvimento da CIDH dentro ou fora da IES? Eis os resultados:

Quadro 10 - Atores externos e internos da CIDH, conforme participantes do GF.

\begin{tabular}{|c|c|}
\hline $\mathbf{P}$ & Fragmentos de falas \\
\hline B1: & “[...] OMG [...]” \\
\hline B2: & “[...] Casa de Cultura [...]” \\
\hline B3: & “[...] município, por meio das secretarias municipais [...]” \\
\hline B4: & “[...] Empresários [...]” \\
\hline B5: & "[...] Corpo de bombeiro, polícia militar, presidente de bairro [...]" \\
\hline B6: & "[...] Presidente de bairro, escolas [...]" \\
\hline B7: & “[...] escola do bairro [...]” \\
\hline B8: & “[...] nossa comunidade acadêmica [...]” \\
\hline
\end{tabular}

Fonte: As Autoras, (Q3, GF2, 19/09/2018)

A participação de atores externos à comunidade acadêmica, evidencia que o aprendizado não se dá apenas centrado na figura do professor, dentro de sala de aula, rompe-se assim, com a visão tradicional do ensino, onde além do aluno ser autor do seu conhecimento, tal saber é adquirido na própria vivência e realidade social. Deste modo, a CIDH UnirG permitirá aos estudantes, participarem de um espaço privilegiado de intercâmbio 
e comunicação entre a investigação acadêmica e os agentes políticos e sociais. Para isso, as propostas curriculares dos cursos permitem este trabalho na graduação, conforme visto no estudo dos PPC dos cursos.

Figura 7 - Atores externos parceiros na CDH UnirG

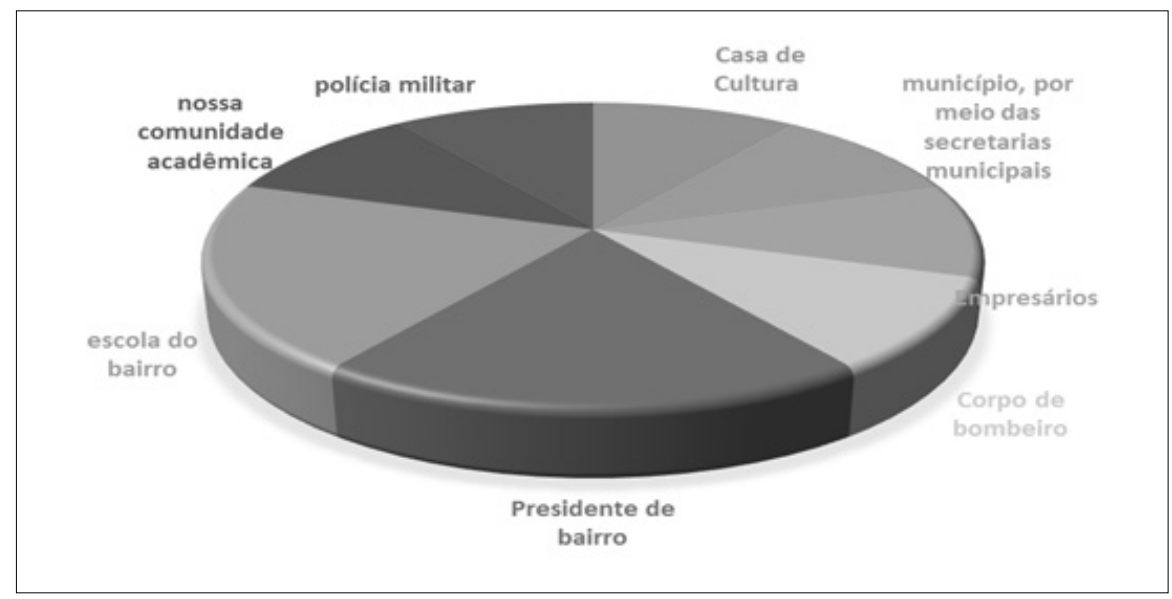

Fonte: As autoras, (Q3, GF2, 19/09/2018)

Nesse sentido, a CIDH UnirG demanda a criação de uma ampla rede de contatos e sinergias que podem garantir a tomada de decisões, considerando vários e diversos elementos, necessários para o desenvolvimento de suas atividades. Outrossim, em um prazo mais alongado, quiçá surja espaço para intercâmbio entre outras instituições de ensino também.

Reforça-se esta conclusão com o questionamento abaixo. Direcionando as discussões sobre o público alvo, indagou-se: Quando se pensa nesta $\mathrm{CIDH}$, que tem como eixo temático Saúde e Qualidade de vida, dentro da IES, em seu curso, considerando os atores internos, qual é o público alvo externo da $\mathrm{CDH}$ ? 
Quadro 11 - Público externo alvo da CDH, conforme participantes dos GF

\begin{tabular}{|c|c|}
\hline $\mathbf{P}$ & Fragmentos de fala dos participantes \\
\hline B1: & “[...] adolescentes [...] como ator principal [...]” \\
\hline B2: & “[...] as crianças de 7 a 8 anos de idade [...]" \\
\hline B3: & $\begin{array}{l}\text { "[...] comunidade em geral, até coloquei comunidade de Gurupi e } \\
\text { cidades circunvizinhas [...]" }\end{array}$ \\
\hline B4: & $\begin{array}{l}\text { "[...] precisa com certeza atender crianças, jovens e mas eu não } \\
\text { quero desistir do adulto e nem do idoso [...]" }\end{array}$ \\
\hline B5: & $\begin{array}{l}\text { "[...] eu pensei no grupo ... grupo de adolescentes, e o grupo da } \\
\text { criança, grupo do Idoso [...]" }\end{array}$ \\
\hline B6: & $\begin{array}{l}\text { “[...] grupo composto por todos os alunos e professores ..." cada um } \\
\text { com sua área [“...]” }\end{array}$ \\
\hline B7: & “[...] Populações diferenciadas [...]” \\
\hline B8: & “[...] escolher um bairro que é mais propício [...]” \\
\hline
\end{tabular}

Fonte: As Autoras, (Q4, GF2, 19/09/2018).

A escolha por crianças e adolescentes, evidencia a vontade de se realizar um trabalho tanto nas ações de prevenções quanto na de promoção dos direitos. Dos oito participantes, três preferem o trabalho com crianças, e não excluem o jovem adolescente, seja morador de Gurupi ou não. Destaque-se a menção a população diferenciada, atrai um público vulnerável socialmente. As respostas apresentadas, na verdade se complementam e não significam a eleição de um único público certo e determinado, apenas indicam caminhos de escolha para o público alvo a ser atendido.

Em razão de ser a violência uma constante social, cujas crianças são as principais vítimas, o trabalho de conscientização, educação, pode surtir efeitos em longo prazo, na comunidade local. De maneira mais ou menos intuitiva, os participantes demonstram que a concepção de interesse público deste trabalho relaciona-se a bens e serviços que afetam toda a cidadania infanto-juvenil, com elementos de organização política e social essenciais. 
Quadro 12 - Outros atores externos e internos da $\mathrm{CDH}$, conforme participantes.

\begin{tabular}{|c|l|}
\hline P & Fragmentos de fala dos participantes \\
\hline B1: & $\begin{array}{l}\text { "[...] os casos seriam selecionados por estudantes e professores } \\
\text { por entenderem ser um caso emblemático que necessite de } \\
\text { uma intervenção [...]" }\end{array}$ \\
\hline B2: & "os professores e os alunos selecionariam os casos emblemáticos" \\
\hline B3: & $\begin{array}{l}\text { "[...] o bairro mais violento, com maior índice de criminalidade, e } \\
\text { a partir dali o professor escolheria o caso emblemático junto com } \\
\text { seus alunos para trabalhar aquele caso [...]" }\end{array}$ \\
\hline B4: & "[...] No início nós que vamos até lá, e depois eles que vem até nós $[. .] "$. \\
\hline B5: & "[...] listas de pessoas de espera, aí tem que ter uma equipe $[. .] "$. \\
\hline B6: & "[...] triagem [...]" \\
\hline B7: & "[...] que o ideal seria a triagem mesmo [...]" \\
\hline
\end{tabular}

Fonte: As Autoras, (Q4, GF2, 19/09/2018)

A concepção do grupo de trabalho para a seleção dos casos, pressupõe uma ação coletiva de professores e alunos, os quais, através de uma visita no local, primeiramente, selecionarão os casos emblemáticos a serem trabalhos, via de uma triagem. A abordagem poderá se realizar em todas as atuações, desde a sensibilização, a formação da cidadania, a participação em processos de elaboração, desenvolvimento e execução de políticas públicas, quanto nas atividades de lobby, dentre outras.

Há de se ressaltar a importância do resguardo da autonomia universitária neste cenário, para além da simples eleição dos temas ou grupos a serem trabalhados, mas também a garantia da metodologia a ser escolhida, em vista sempre da vocação, objetivo de criação e pedagógico da CIDH UnirG. Assim, imprescindível a abertura de um espaço para reflexão crítica dos próprios estudantes e professores envolvidos, com mecanismos de avaliação, reflexão, autocrítica, e manifestações amplas.

Em seguida, passou-se a discutir quem seriam as pessoas, qual o pensamento do grupo sobre essa triagem e encaminhamentos. 
Quadro 13 - Formas de triagem dos atendimentos, conforme participantes.

\begin{tabular}{|c|l|}
\hline P & Fragmentos de fala dos participantes \\
\hline B1: & “[..] Essa clínica tem que ter seu Regimento $[\ldots] "$ \\
\hline B2: & "[...] educação e Psicologia $[. .] "$. \\
\hline B3: & “[..] um grupo $[\ldots] "$ \\
\hline B4: & "[...] grupo define $[\ldots] "$ \\
\hline B5: & "[...] um grupo $[\ldots] "$ \\
\hline B6: & "[...] direcionamento em função da própria gravidade $[\ldots] "$ \\
\hline
\end{tabular}

Fonte: As Autoras, (Q5, GF2, 19/09/2018)

A partir das ponderações do grupo, percebe-se a convergência quanto a necessidade de uma triagem, inclusive já sinalizada no item anterior, realizada por um grupo, o qual deverá conhecer bem o funcionamento da $\mathrm{CIDH}$, para que se faça encaminhamentos dos atendimentos, aos núcleos específicos, considerando a gravidade da situação apresentada. Esta é uma solução, inicialmente pensada para os casos específicos. Contudo, dentro da Clínica de Direitos Humanos, onde as intervenções deverão ser macros, de modo a atingir toda a coletividade, as ações de intervenção deverão ser repensadas pela equipe participante. Este encaminhamento pode ter sido apresentado, e até mesmo pela falta de conhecimento empírico sobre o funcionamento das demais CDH existentes.

Sobre o direcionamento propriamente dito, foi indagado: Como que você pensa que sejam direcionamento das pessoas selecionadas?

Quadro 13 - Formas de direcionamento dos atendimentos, conforme participantes

\begin{tabular}{|c|l|}
\hline P & Fragmentos de fala dos participantes \\
\hline B1: & "[...] o atendimento tem que ser gratuito [...]" \\
\hline B2: & "[...] ter uma contra partida daquele grupo que está sendo atendido $[. .] "$. \\
\hline B3: & $\begin{array}{l}\text { "[...] ela sente valorizada ...então mesmo que seja alguma coisa } \\
\text { meio simbólica }[\ldots] "\end{array}$ \\
\hline B4: & "[...] Doação $[\ldots .]$.
\end{tabular}




\begin{tabular}{|c|c|}
\hline B5: & "[...] não faltar aos encontros de dois ou três [...]" \\
\hline B6: & "[...] trabalhar o empoderamento pessoa [...]" \\
\hline B7: & $\begin{array}{l}\text { "[...] a responsabilidade dela no sentido de cumprir agenda, cumprir } \\
\text { com as obrigações }[. . .] "\end{array}$ \\
\hline B8: & "[...] Um trabalho de evolução [...]" \\
\hline B9: & $\begin{array}{l}\text { "[...] a evolução da pessoa nesse plano de trabalho.pessoa pode ser } \\
\text { convidado a ser voluntário }[. . .] "\end{array}$ \\
\hline B10: & "[...] relatório final dessa pessoa [...]" \\
\hline B11: & "[...] a intervenção também tem que ser coletiva $[. .] "$. \\
\hline B:12 & $\begin{array}{l}\text { "[...] esse plano tem que ser em comum, senão não vai ser } \\
\text { interdisciplinar }[. . .] "\end{array}$ \\
\hline
\end{tabular}

Fonte: As Autoras, (Q6, GF 2, 2018).

A partir desta discussão, com os apontamentos acima, extraiuse uma preocupação do grupo para com a modificação do padrão de comportamento do assistido, incluindo a necessidade de um retorno a este, como tarefa educativa e empreendedora, prestando contas dos serviços realizados, bem como promovendo uma "evolução" em seu padrão de comportamento. Vê-se também uma preocupação com trabalho estratégico, a ser desenvolvido através de plano de ação, cuja construção deverá ser coletiva, de modo a preservar a interdisciplinaridade. Veja a fala destacada abaixo:

“Aí no grupo, a pontualidade daquele grupo, a gente escolhe uma temática,
por exemplo violência dentro do bairro, da Vila São José, que é emblemá-
tico em Gurupi. O que o grupo poderia fazer, qual o plano de ação que nós
vamos traçar dentro desse bairro, a melhoria na qualidade de vida, em
termos coletivo é isso? Planejamento estratégico mesmo?" (Participante
B1I, Grupo focal 2, Q)

Uma evidência extraída também, é que ainda permanece para os docentes participantes da pesquisa, a visão de que os serviços de atendimento devem ser prestados pelos cursos isoladamente junto aos assistidos. Nesse aspecto, deve-se adotar muita cautela para que a CIDH da UnirG não se torne apenas uma central de atendimento de seus diversos 
cursos, e perca seu foco de trabalho voltado para o coletivo social e para as práticas de ensino, voltada inclusive para interdisciplinaridade.

A finalidade da Clínica de Direitos Humanos proposta é ser um espaço alternativo que promova aos estudantes dos cursos uma aprendizagem da práxis dos Direitos Humanos, a integração simultânea de atividades de ensino, pesquisa e extensão, com compromisso ético e social. 0 aluno deverá desenvolver habilidades profissionais, aprender com a experiência, adquirir responsabilidade profissional, trabalho colaborativo, impacto do conteúdo programático de seu curso na vida real, através de uma mentalidade crítica.

Imprescindivel transpor a barreira do mero assistencialismo a casos individuais, valorizados em seu momento oportuno, e a educação amplamente tecnicista, dogmática e positivista, especialmente, a jurídica. Importante frisar o contato do discente com a realidade social na qual está inserido, com os direitos em uma escala mundial e o exercicio da argumentação para propor solução para problemas de interesse público.

\section{CONSIDERAÇÕES FINAIS}

O esperado do trabalho é o alcance de benefícios em diversas áreas: na produção científica com a divulgação dos dados através de artigos, resumos, dentre outros; na formação da comunidade acadêmica, através do compartilhamento das diversas experiências na temática da interdisciplinaridade, bem como no desenvolvimento coletivo de um projeto acadêmico. Quanto ao retorno dos conhecimentos produzidos e benefícios sociais, espera-se que os envolvidos sejam multiplicadores do conhecimento em prol da Universidade, e na melhoria da prestação dos serviços, tanto acadêmicos quanto sociais para a comunidade.

0 modelo clínico de ensino traz o potencial de renovar as perspectivas pedagógicas relacionadas ao ensino superior, transpondo o atendimento individual prestado pelos cursos, extremamente importante também para o ensino e para a população, e os horizontes tecnicistas, dogmáticos e positivistas que tem caracterizado a educação superior nacional. Este modelo tende a ultrapassar a "educação bancária", expressão de Paulo 
Freire, e da mera aplicação dos conhecimentos teóricos e técnicos a um caso específico, atendido individualmente, passando para uma escala maior, integrada à realidade social, com o exercício da argumentação, a fim de construir e propor soluções para problemas de interesses públicos.

Cuida-se por isso, de uma modificação nas expectativas acadêmicas e na visão profissional discente e docente, convidando-os a ultrapassar o ensinamento limitado aos prédios universitários e enfrentar as problemáticas da sociedade face a face, através de estratégias que, no mais das vezes, superam os limites disciplinares do ensino, entre as diversas tendências de pensamento, constata-se uma visão holística, a qual oferece pistas para encontrar novos pressupostos e propostas educacionais. Não se ignora que o olhar holístico requer ainda estudos e reflexões de pesquisadores a fim de redirecionar melhor sua aplicação, pois sua abordagem em educação não é propriedade de uma única corrente educacional. Diversas correntes pedagógicas já propuseram cada uma ao seu modo, uma educação integral da pessoa.

A UnirG, via de seus cursos de graduação, e confirmados nos grupos focais, presta relevante serviço social, atendendo a comunidade carente, porém, centrada no assistencialismo e ensino individual, sem uma integração entre os cursos. Não se desmerece essa prestação de serviços, importante tanto para o ensino quanto para a comunidade em geral. Porém, carece a academia de um projeto maior, integrando seus cursos, e desenvolvendo problemáticas maiores, emblemáticas, voltadas para os Direitos Humanos.

Nesse diapasão, as reuniões dos grupos focais, confirmaram que todos os cursos se veem integrados e trabalhando em conjunto de maneira produtiva, e até mesmo carecem de outros ramos do conhecimento para melhoria de seus próprios serviços. Evidenciou-se então, a abertura necessária, dentro do corpo docente, para a construção coletiva da proposta interdisciplinar. Mostrou-se possível e bem vista a articulação das ações e estudos propostos na perspectiva de intervir na realidade social deste município para transformá-lo, mas também para construir um novo paradigma ao ensino universitário, na perspectiva de formar profissionais, que sejam, antes de tudo, cidadãos preocupados com o seu 
papel na sociedade e busca da superação das desigualdades sociais, até mesmo para servir como modelo para outras instituições.

Relevante notar ainda a possiblidade de contribuição para humanização do próprio aluno, o qual é educado de forma isolada de outras profissões, e até mesmo da comunidade, "muito técnico (...) não se preocupa com o outro" (B12,12/09/2018), sugerindo um isolamento acadêmico e social. Percebe-se, na UnirG, a ausência de uma política institucional efetiva de apoio a propostas pedagógicas incentivadoras da interdisciplinaridade entre os cursos desta instituição, a qual poderia integrar e incentivar a interligação dos ramos dos saberes.

Os participantes veem o professor numa posição confortável para trabalhar numa proposta pedagógica interdisciplinar, de forma a complementar os métodos, os conceitos, as estruturas e os dogmas sobre os quais se sedimentam as práxis pedagógicas das disciplinas científicas. Vê-se como positiva o pensamento inovador, da qual resulta uma troca, reciprocidade e integração entre áreas diversas de conhecimento.

Portanto, identificou-se que falta um espaço nos cursos da UnirG que promova uma educação para formar defensores de Direitos Humanos e/ou profissionais com mais domínio teórico e prático para intervenções sobre problemas reais de Direitos Humanos, assim como mais sensibilizados para utilizar seus conhecimentos como meio de transformação social. A conclusão desta pesquisa é que uma educação clínica em Direitos Humanos, concebida de maneira interdisciplinar, é uma maneira de proporcionar um espaço de formação que contribua para preencher essa carência nos cursos do UnirG. E, como produto da presente pesquisa, foi protocolado o Projeto de Extensão "CLINICA INTERDISCIPLINAR DE DIREITOS HUMANOS UNIRG - CIDH UnirG”, sob a coordenação da primeira autora.

\section{NOTAS}

1 Lei Municipal no 1.566 de 18 de dezembro de 2003 e Lei Municipal n 1.699 de 11 de julho de 2007.

2 Parecer Comitê de Ética n. 2.832.162 


\section{REFERÊNCIAS}

BEYTÍA, P. Creatividad situada, contingencia y modernidad. Entrevista a Hans Joas. In: Revista Andamios, 2012, p. 378. Disponível em: https://www.redalyc. org/toc.oa?id=628\&numero=24428 Acesso em 04/12/2018

BRASIL. Congresso Nacional. Lei 9394, de 20 de dezembro de 1996. Diretrizes e bases da educação nacional. Brasília, 1996.

BRASIL. Ministério da Educação. CNE/CEB. Câmara de Educação Básica. Resolução n. 2, de 02 de abril de 1998: Institui as Diretrizes Curriculares Nacionais para o Ensino. Brasília. 1998.

BRASIL. Secretaria de Direitos Humanos da Presidência da República. Educação em direitos humanos: diretrizes nacionais. Brasília: SDH/PR, 2013.

CARDOSO, C.M. Revista Interdisciplinar de Direitos Humanos: uma contribuição para o diálogo entre a ciência, a ética e a política. Revista Interdisciplinar de Direitos Humanos, v. 1, n. 1, p. 7-14, 2013.

COURTIS, C. La educación clínica como práctica transformadora. In: VILLAREAL, M.; COURTIS, C. (coords.). Enseñanza clínica del derecho: una alternativa a los métodos tradicionales de formación de abogados. México: ITAM, 2007. p. 9-24.

FAZENDA, Ivani Catarina Arantes. Interdisciplinaridade: história, teoria e pesquisa. 2. ed. São Paulo: Papirus, 1995.

FAZENDA, I. C.A. Reflexões metodológicas sobre a tese: "interdisciplinaridadeum projeto em parceria". Metodologia da pesquisa educacional, v. 9, p. 123-139, 2002.

FREIRE, P. Educação "bancária" e educação libertadora. Introdução à psicologia escolar, v. 3, p. 61-78, 1997.

JAPIASSU, H. Interdisciplinaridade e patologia do saber. Rio de Janeiro: Imago, 1976.

LAPA, F.B. Clínica de direitos humanos: uma proposta metodológica para a educação jurídica no Brasil. São Paulo, Lumen Juris. 2014 
MORIN, E. Educação e complexidade, os sete saberes e outros ensaios. São Paulo: Cortez, 2005.

OLIVEIRA, A. F. Políticas públicas educacionais: conceito e contextualização numa perspectiva didática. In; OLIVEIRA, A.F.; PIZZIO, A.; FRANÇA, G. (org). Fronteiras da Educação: desigualdades, tecnologias e políticas. Goiânia: PUC Goiás, 2010, p. 93-99.

OLIVEIRA, E.B. A interdisciplinaridade na perspectiva de integrar as disciplinas da área de Ciências da Natureza e Matemática. 2016, 221 fl.. Dissertação (Mestrado em Ensino na Educaão Básica). Universidade Federal do Espírito Santo. 2016. Disponível em: <http://portais4.ufes.br/ posgrad/teses/tese_9570_08\%20-\%20Elisandra\%20Brizolla\%20de\%20 Oliveira20161130-153427.pdf> Acesso em: 15 Ago.2018.

RIBEIRO, C.F.T. Clínica de Direitos Humanos da Amazônia. In: SILVA NETO, N. M.; RIBEIRO, C.F.T.; LOUREIRO, S. M. S.; LIMA, G. G. B.; MESQUITA, V. J. C.; SANTOS, J.L.R.; MENDES, B. C. Educação Clínica em Direitos Humanos: Experiência da Rede Amazônica de Clínicas de Direitos Humanos. São Paulo: Lumen Juris, 2016, p. 09-20.

RODRIGUES, H. W. et al. 0 ensino juridico de graduação no Brasil, contemporaneo: analise e perspectiva de Roberto Lyra Filho. 2007.

RODRIGUES, Z. B. Os quatro pilares de uma educação para o século XXI e suas implicações na prática pedagógica. Disponível em: < http://www.educacional. com.br/articulistas/outrosEducacao_artigo.asp?artigo=artigo0056> Acesso 10 Fev. 2018.

SEVERO, C. G.; DE PAULA, A. C. No mundo da linguagem: ensaios sobre identidade, alteridade, ética, política e interdisciplinaridade. Pedro \& João Ed., 2010.

SILVA NETO, N. M.; RIBEIRO, C. F. T.; LOUREIRO, S. M. S.; LIMA, G.G.B.; MESQUITA, V.J.C.; SANTOS, J. L.R.; MENDES, B.C. Educação Clínica em Direitos Humanos: Experiência da Rede Amazônica de Clínicas de Direitos Humanos. São Paulo: Lumen Juris, 2016. 
SIQUEIRA , H. S. G. Formação interdisciplinar: exigência sócio-política para um mundo em rede. Simpósio Estadual de Economia Doméstica, 7, 2003, Francisco Beltrão, PR. Anais eletrônico.Francisco Beltrão, PR: UNIOESTE, 2003. Disponível em: http://www.angelfire.com/sk/holgonsi/mundorede.html. Acesso 10 Set. 2017.

THIESEN, J. S. A interdisciplinaridade como um movimento articulador no processo ensino-aprendizagem. Rev. Bras. Educ. [online]. 2008, vol.13, n.39, pp.545-554. ISSN 1413-2478. http://dx.doi.org/10.1590/S141324782008000300010.

UNIRG, Centro Universitário. Plano de Desenvolvimento Institucional (PDI). 2017.

VILLARREAL, M.; COURTIS, C. (Ed.). Enseñanza clínica del derecho: Una alternativa a los métodos tradicionales de formación de abogados. CLIP, Clínica Legal de Interés Público, 2007.

ZENAIDE, M. N. T. et al. Políticas de extensão universitária e a disputa pela: a questão dos direitos humanos na UFPB. 2010.

Recebido em: 07-12-2018

Aprovado em: 26-10-2020 


\section{Jaqueline de Kassia Ribeiro de Paiva}

Doutorado em Ciências Jurídico-Sociais - Universidad del Museo Social Argentino (2019). Mestre em Gestão de Políticas Plúblicas - UFT (2019). Graduação em Ciências Jurídicas pela Faculdade de Filosofia e Ciências Humanas de Gurupi (1999). Especialista em Desenvolvimento Sustentável e Direito Ambiental - UNB (2005). Advogada e professora titular da Universidade de Gurupi e Unitins, membro - Ordem dos Advogados do Brasil - Seção Tocantins e Secretária Geral da Ordem dos Advogados do Brasil - Subseção Gurupi. Sócia-fundadora do Escritório Ribeiro e Pereira Advogadas. Facilitadora de Justiça Restaurativa. Experiência na área de Direito, com ênfase em Direito Penal, Ambiental, Família e Consumidor. E-mail: jakpaiva1@hotmail.com

\section{Juliana Ricarte Ferraro}

Doutorado em Educação pela Universidade de São Paulo/USP. Mestrado em História pela Universidade Estadual de Campinas (2002). Graduação (lienciatura e bacharelado) em História pela Universidade Estadual Paulista Júlio de Mesquita Filho (1998). Especialização em Restauro e Conservação de Documentação Gráfica pela Faculdade Senai de São Paulo (2003). Professora Adjunto III da UFT - Universidade Federal do Tocantins, no curso de História. Atuando nos seguintes temas: História Cultural, Leitura, Livro e Manuais Escolares, Educação e Ensino de História, Patrimônio Histórico, Conservação e Restauro de Documentação Gráfica e Arquivos. E-mail: juferraro@mail.uft.edu.br

\section{Lady Sakay}

Doutorado em Educação pela Universidade de Brasilia. Mestrado em Educação pela Universidade de Brasilia. Graduação em Pedagogia pela Faculdade de Filosofia e Ciências Humanas de Gurupi. Reitora e professora titular II do Centro Universitário UnirG de Gurupi. Coordenadora do Grupo d e Pesquisa Processos Educativos do Centro Universitário UnirG. Experiência na área de Gestão da Educação Superior, Educação Matemática, Educação Corporativa e EaD. Também já atuou como assessora técnica na capacitação presencial dos avaliadores do SINAES (INEP/UnB) e Consultora Pedagógica do CESPE/UnB. Atua principalmente nos seguintes temas: Gestão da Educação, Educação Matemática, Educação Corporativa e Formação Continuada; Educação indígena; Educação e Saúde; Educação ambiental. E-mail: lady.sakay@gmail.com

Fundação Unirg, Coordenação do Curso de Ciências Jurídicas, Escritório Modelo de Direito.

Avenida Rio Grande do Norte, esq. com rua 03

Setor Central - Gurupi, TO -77403090 